\title{
MODEL LATIHAN SERVIS TIPUAN (TRICK SERVICE) SEPAK TAKRAW PEMULA
}

\author{
Oleh : Dadang Budi Hermawan \\ STKIP Sebelas April Sumedang \\ dadangb79@gmail.com
}

\begin{abstract}
Abstrak
Tujuan artikel ini menghasilkan model latihan Servis Sepak Takraw. Selain itu, artikel dibuat untuk memperoleh informasi yang lebih mendalam dan akurat mengenai model latihan, efektivitas dan efisiensi model latihan yang dibuat. Sampel atlet pemula yang tergabung dalam club sepak takraw kabupaten Sumedang. Hasil artikel ini bentuk variasi latihan, serta mempercepat peningkatan kemampuan atlet dalam mencapai kompetensi servis sepak takraw yang optimal. Termasuk di dalamnya enam variasi latihan servis tipuan (trick service) sepak takraw. Hasil penerapan model ini, dengan beberapa tes, yaitu uji efektivitas model menggunakan instrumen tes yang telah ditentukan. Analisis data penelitian menggunakan uji t dengan taraf signifikansi 0.05. Analisis data diperoleh nilai rata-rata keterampilan servis sepak takraw atlet sebelum diberikan model yang dikembangkan adalah 12,155 dan setelah diberikan perlakuan model latihan yang dikembangkan, nilai rerata dari sampel sejumlah 50 atlet adalah 215,62 artinya model yang dikembangkan tersebut mengalami peningkatan dengan diperoleh data hasil t-hitung $=-111,387 \mathrm{df}=49$ dan -value $=0.00<0.05$. Hal ini berarti, terdapat perbedaan yang signifikan antara kemampuan servis sebelum dan sesudah diberikan perlakuan, yaitu penerapan model latihan servis sepak takraw untuk atlet pemula Kabu paten Sumedang. Berdasarkan keterangan tersebut dapat dikatakan bahwa model latihan untuk atlet pemula yang dikembangakan efektif dan dapat meningkatkan kemampuan servis sepak takraw dengan optimal.
\end{abstract}

Kata kunci: Model, Sepak Takraw, Atlet Pemula

\section{THE TRICK SERVICE TRAINING MODEL ON THE BEGINNER OF SEPAK TAKRAW}

\begin{abstract}
The purpose of this article is to produce the Sepak Takraw service training model. In addition, the article was made to obtain more in-depth and accurate information about the training model, the effectiveness and efficiency of the training model created. Samples of beginner athletes who are members of the Sepak Takraw Sumedang district. The results of this article form a variety of exercises, as well as accelerate the increase in the ability of athletes to achieve optimum Sepak Takraw competence. This includes six variations of sepak takraw's trick service practice. The results of the application of this model, with several tests, namely testing the effectiveness of the model using predetermined test instruments. Analysis of research data using t test with a significance level of 0.05 . Analysis of the data obtained the average value of Sepak Takraw athlete service skills
\end{abstract}


before given the developed model is 12,155 and after being given treatment the developed training model, the average value of a sample of 50 athletes is 215.62 meaning that the developed model has increased with the results obtained t-count $=-111,387 \mathrm{df}=$ 49 and $p$-value $=0.00<0.05$. This means, there is a significant difference between the ability of service before and after treatment, namely the application of the Sepak Takraw service training model for beginner athletes of the Sumedang district. Based on this information it can be said that the training model for beginner athletes is developed effectively and can improve the ability of Sepak Takraw service optimally.

Keywords: Model, Sepak Takraw, Beginner Athlete Correspondence author: Dadang Budi Hermawan, STKIP Sebelas April Sumedang, Indonesia.
Dadangb79@gmail.com

(c) (1) (2)

Jurnal HalamanOlahraga Nusantara licensed under a Creative Commons Attribution-ShareAlike 4.0 International License.

\section{PENDAHULUAN}

Pada intinya model-model latihan yang diberikan masih belum bervariasi, dampak negatif dari proses latihan servis yang kurang bervariasi adalah: (1) kurang dapat mengembangkan teknik dasar servis sepak takraw dengan baik; (2) kurang memahami gerakan dan tujuan latihan teknik dasar servis sepak takraw; (3) kurang melakukan servis sepak takraw dengan berbagai sasaran; dan (4) pencapian hasil latihan servis sepak takraw kurang optimal.

Gerakan dasar yang salah akan menyulitkan untuk mengembangkan gerakan lanjutannya. Hal ini dapat kita amati, pada awal perkembangan sepak takraw di Kabupaten Sumedang, latihan servis pada saat permainan sepak takraw dilakukan secara bertahap (sistematis), hitungan pertama satu kaki (kaki tumpu) melangkah memasuki lingkaran dan kaki ayun berada di luar lingkaran, hitungan kedua salah satu tangan meminta arah lambungan bola kepada apit sesuai yang diinginkan, hitungan ketiga (kaki sepak) mengarahkan dan menendang bola hasil lambungan dari apit. Setelah bola disepak gerak lanjutan tubuh mengikuti gerakan lanjutan kaki sepak untuk menjaga keseimbangan. Tahapan latihan servis di atas, berbeda dengan tahapan latihan servis yang dilakukan sekarang. Dewasa ini, pelatih 
membelajarkan servis sepak takraw pada pemula secara langsung dengan menggunakan media seperti bola digantung. Kelemahannya tekong pemula yang mulai belajar servis memiliki kesulitan dalam mempelajari dan mengarahkan bola hasil servis dengan menggunakan berbagai jenis servis. Berbeda dengan tekong yang pertama kali belajar servis sepak takraw secara bertahap (sistematis), karena dengan penguasaan gerakan dasar tersebut, tekong lebih mudah untuk dikembangkan dalam mempelajari servis sepak takraw, sehingga tekong pemula bukan hanya mampu melakukan servis bawah saja, namun bisa melakukan berbagai variasi servis.

Analisis kebutuhan yang telah dilakukan peneliti bermaksud untuk mengembangkan model-model latihan servis untuk pemula di club sepak takraw Sumedang. Pada akhirnya melalui model latihan servis ini diharapkan mampu memperkaya khasanah keilmuan pada bidang sepak takraw, khususnya untuk pelatih sepak takraw di club Sumedang.

\section{METODE}

Penelitian merupakan cara ilmiah yang berlandaskan keilmuan seperti rasional, empiris, dan sistematis dalam memecahkan suatu permasalahan. Penggunaan metode ilmiah dalam penelitian merupakan suatu cara agar penelitian mencapai tujuan sesuai harapan dan berguna dalam kehidupan. Penelitian pada dasarnya adalah suatu kegiatan atau proses sistematis untuk memecahkan masalah yang dilakukan dalam penerapan metode ilmiah. Secara umum metode penelitian diartikan sebagai cara ilmiah untuk mendapatkan data dengan tujuan dan kegunaan tertentu. Emzir Penelitian mengemukakan, "Suatu kegiatan atau proses sistematis untuk memecahkan masalah yang dilakukan dengan metode ilmiah"(Emzir 2008)

Dalam hal pendidikan, Borg and Gall (1983) mendefinisikan, "education $R \& D$ is an industry based development model in which the findings of the research are used to desain new products and procedures, which they are systematically filed-taste, evaluated, and revined until they meet specified criteria of effectiveness, quality, or similar standard" 
Peneliti dapat melakukan berbagai bentuk penelitian, seperti penelitian dasar, terapan, evaluasi, deskripsi, prediktif, dan pengembangan. Penelitian pengembangan (development research) menghasilkan pola, urutan pertumbuhan, dan perubahan untuk mengembangkan produk yang salah satunya dapat berupa bahan ajar. Pengembangan bahan ajar juga berupa buku ajar, alat peraga, dan modul pembelajaran. Dalam prosesnya penelitian pengembangan merupakan penelitian yang tidak digunakan untuk menguji teori, melainkan hasil penelitian di lapangan kemudian direvisi sampai hasilnya memuaskan. Penelitian dan pengembangan (Research and Development) menurut Borg \& Gall adalah, "Suatu proses yang dipakai untuk mengembangkan dan memvalidasi produk pendidikan" (Borg and Gall 1983).

Menurut Putra (2011), "Penelitian dan pengembangan adalah suatu istilah yang digunakan untuk menggambarkan aktivitas yang berhubungan dengan penciptaan atau penemuan baru, metode, dan produk atau jasa baru dengan menggunakan pengetahuan baru yang ditemukan untuk memenuhi kebutuhan pasar atau permintaan”. Selanjutnya Punaji mengemukakan tentang penelitian pengembangan adalah, "Sebagai kajian secara sistematik untuk merancang, mengembangkan, mengevaluasi program-program dan proses hasil pembelajaran yang harus memenuhi kriteria konsistensi dan keefektifan secara internal.(Setyosari 2013)

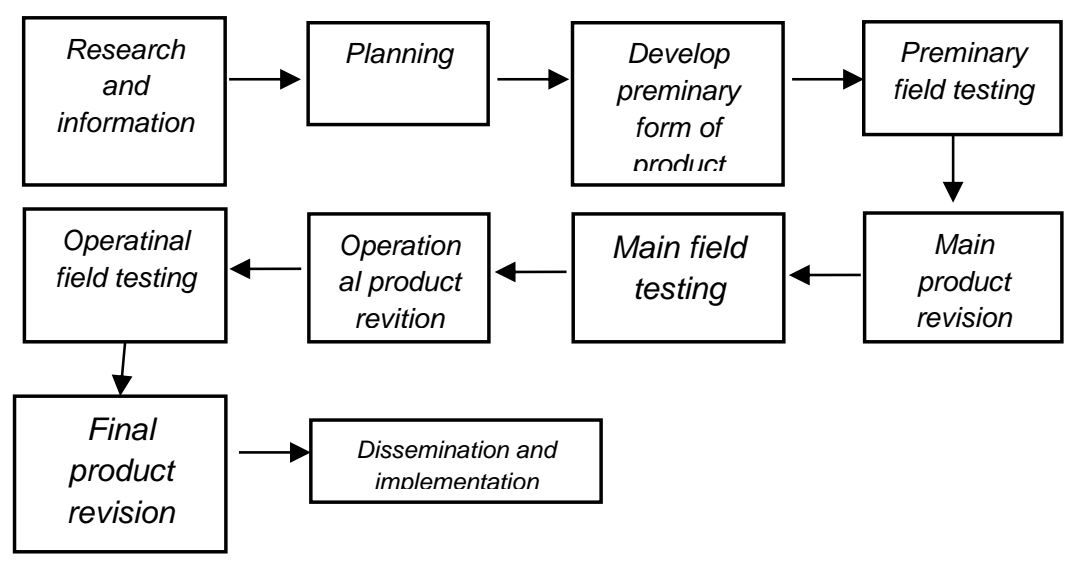

Gambar. 1 Instructional Design $R$ and $D$ 
Gambar di atas mendeskripsikan langkah-langkah penelitian dan pengembangan suatu produk yang dapat dipertanggungjawabkan dan diwujudkan dalam bentuk teknis sasaran serta jenis kegiatan yang dilakukan pada setiap tahapannya. Setiap langkah-langkah tersebut bukanlah hal yang bersifat baku, tetapi langkah tersebut dapat disesuaikan dengan kebutuhan setiap peneliti.

\section{HASIL DAN PEMBAHASAN}

Berikut merupakan data responden sebagaimana dimaksud :

Tabel 1 Profil Responden.

\begin{tabular}{lll}
\hline Total Sampel & Intansi & Informan / Pelatih \\
100 orang & SMPN 1\& 2 Conggeang & 1. Iin Firmansyah \\
& 2. Cece Sumiarsa \\
& 3. Yogi Subarjah \\
& 4. Indra Setiawan \\
& 5. Teguh Rambo \\
\hline
\end{tabular}

100 orang sampel dengan jenis kelamin laki-laki tersebut, merupakan gabungan dari dua SMP Negeri 1 dan SMP Negeri 2 Conggeang. Mediator antara peneliti dengan sampel dalam penelitian ini adalah pelatih dan pelatih asisten pada jenis olahraga permainan sepak takraw Kabupaten Sumedang. Pelaksanaan penelitian dilakukan di tempat pembinaan atlet dan calon atlet Sepak Takraw Kabupaten Sumedang mulai dari O2SN sampai pada pembentukan atlet PORDA dan POPDA. Adapun Club yang mewadahi pembinaan tersebut dinamakan Sepak Takraw Sumedang Club yang menyandang status sebagai satu-satunya club olahraga Sepak Takraw di Kabupaten Sumedang serta dinaungi oleh PENGCAB PSTI Kabupaten Sumedang.

\section{1) Pengembangan Model}

Hasil pengembangan dari model latihan servis sepak takraw untuk pemula dideskripsikan dalam bentuk naskah atau pedoman pelaksanaan yang disajikan dan dibaca untuk keterampilan servis sepak takraw yaitu, Sepak mula gaya bebas (free style service), Sepak mula tajam, (spike service), Sepak mula tinggi (lob service), Sepak mula tipuan (trick service), Sepak mula sudut (corner/angle service), dan Sepak mula didepan net lawan (flash service). 
Terdapat beberapa tujuan analisis kebutuhan yang akan diungkap pada studi pendahuluan atau analisis kebutuhan seperti yang diuraikan sebagai berikut.

1. Untuk mengetahui kondisi yang sebenarnya terjadi mengenai penyampaian model-model latihan servis sepak takraw kepada atlet pemula di klub sepak takraw Sumedang;

2. Untuk mengetahui dibutuhkan atau tidaknya pengembangan model-model latihan servis sepak takraw kepada atlet pemula di klub sepak takraw Sumedang.

Pengembangan model ini merupakan hasil dari permasalahan yang ditemukan di lapangan melalui observasi dan angket kepada atlet dan pelatih beserta pengalaman pribadi sebagai wasit sepak takraw. Berdasarkan hasil data angket dan observasi di lapangan, selanjutnya peneliti melakukan pengolahan dan analisis data agar dapat dideskripsikan dalam bentuk tulisan. Berdasarkan hasil data, dapatdideskripsikan beberapa hal penting antara lain, pelatih sudah membuat jadwal latihan selama lima (5) kali dalam seminggu (Senin, Selasa, Rabu, Kamis, dan Sabtu) sedangkan Jumat dan Minggu digunakan untuk istirahat (rest). Bentuk latihan sevis yang diberikan pelatih kepada atlet pemula adalah latihan servis dasar. Gerakannya sederhana yang penting atlet mampu menyebrangkan bola hasil servis ke lapangan lawan untuk memulai pertandingan. Materi latihan servis belum banyak, hanya menerapkan berbagai macam jenis servis. Bentuk model latihan yang diberikan pelatih kepada atlet adalah melatih gerak servis dasar dengan memadukan target bola digantung. Bentuk latihan ini belum memasukan berbagai komponen kemampuan fisik, hanya menekankan pada rangkaian gerakan saja. Kendala pertama yang dihadapi para atlet pemula ketika melakukan servis adalah perkenaan kaki dengan bola ketika kaki ayun melakukan ayunan sepakan servis (timming). Kendala kedua adalah dari gerakan servis itu sendiri, atlet pemula masih menggunakan gerakan servis yang sederhana (servis bawah), belum menggunakan berbagai jenis servis yang sistematika gerakannya sulit (servis atas). Berbagai upaya melakukan gerakan yang bervariasi masih belum banyak dilakukan dengan bebagai keterbatasan. Model latihan tambahan yang diperlukan 
sebagai variasi adalah model latihan dengan bola yang dilempar dan variasi bola digantung. Model-model latihan dalam bentuk Buku, CD dan alat bantu latihan sangat dibutuhkan. Buku lebih mudah digunakan dan dipelajari atau dibaca dan CD akan mempermudah dalam mempelajari berbagai model yang akan diberikan kepada atlet.

\section{2) Hasil Uji Kelompok Sampel}

Untuk mengetahui seberapa besar pengaruh perlakuan (treatment) yang diberikan kepada kelompok eksperimen, perlu pula dilakukan tes pada kelompok kontrol. Selanjutnya peneliti melakukan uji untuk mengetahui seberapa besar pengaruh pengembangan model terhadap hasil servis,. Berikut ini adalah hasil perhitungan dengan munggunakan aplikasi IMB SPSS Data Editor 21 :

Tabel : 2

\begin{tabular}{llllll}
\hline \multicolumn{2}{l}{ Descriptive Statistics } & & & \\
& N & Mean & Std. & Minimu & Maximu \\
& & & Deviation & $\mathrm{m}$ & $\mathrm{m}$ \\
VAR00001 & 50 & 399,82 & 9,363 & 372 & 413 \\
VAR00002 & 50 & 215,62 & 5,972 & 203 & 226 \\
\hline
\end{tabular}

Tabel : 3

\begin{tabular}{llll}
\hline \multicolumn{2}{l}{ One-Sample Kolmogorov-Smirnov Test } & \\
& & VAR00001 & VAR00002 \\
N & 50 & 50 \\
Normal Parameters & Mean & 399,82 & 215,62 \\
& Std. Deviation & 9,363 & 5,972 \\
Most Extreme Differences & Absolute &, 172 &, 097 \\
& Positive &, 080 &, 087 \\
& Negative &,- 172 &,- 097 \\
Kolmogorov-Smirnov Z & & 1,217 &, 688 \\
Asymp. Sig. (2-tailed) &, 104 &, 731 \\
$\begin{array}{l}\text { a. Test distribution is Normal. } \\
\text { b. Calculated from data. }\end{array}$ & & \\
\hline
\end{tabular}

Tabel : 4

\begin{tabular}{llllll}
\hline \multicolumn{2}{l}{ Paired Samples Statistics } & & & \\
& & Mean & $\mathrm{N}$ & Std. Deviation & Std. Error Mean \\
Pair 1 & VAR00001 & 399,82 & 50 & 9,363 & 1,324 \\
& VAR00002 & 215,62 & 50 & 5,972 &, 845 \\
\hline
\end{tabular}


Berdasarkan hasil uji di atas, terdapat perbedaan yang signifikan antara kelompok eksperimen $\mathrm{T}_{\text {hitung }}=1,324$ dengan kelompok kontrol $\mathrm{T}_{\text {hitung }}=0,845$. Hal ini berarti bahwa kelompok eksperimen memperoleh hasil yang signifikan sedangkan kelompok kontrol tidak memperoleh hasil yang signifikan. Dengan demikian, dapat peneliti simpulkan bahwa perlakuan (treatment) yang diberikan kepada kelompok eksperimen memiliki pengaruh terhadap hasil yang diharapkan, yaitu peningkatan kemampuan pada atlet pemula dalam melakukan servis.

Tabel : 5

\begin{tabular}{llllll}
\hline \multicolumn{2}{l}{ Paired Samples Statistics } & & & \\
\multirow{2}{*}{ Pair 1 } & VAR00001 & Mean & $\mathrm{N}$ & Std. Deviation & Std. Error Mean \\
& VAR00002 & 215,62 & 50 & 9,363 & 1,324 \\
\hline
\end{tabular}

Tabel : 6

\begin{tabular}{|c|c|c|c|c|}
\hline \multicolumn{5}{|c|}{ Paired Samples Correlations } \\
\hline Pair 1 & VAR00001 \& VAR00002 & $\begin{array}{l}\mathrm{N} \\
50\end{array}$ & $\begin{array}{l}\text { Correlation } \\
-, 120\end{array}$ & $\begin{array}{l}\text { Sig. } \\
407\end{array}$ \\
\hline
\end{tabular}

Tabel : 7

\section{Paired Samples Test}

Paired Differences

Mean Std.

Deviatio Mean

$\mathrm{n}$

VAR00001 - $\quad 184,20 \quad 11,693 \quad 1,654$

VAR00002 0
$\mathrm{T}$

Df Sig. (2-

95\% Confidence

Interval of the

Difference

Lower Upper

$180,877 \quad 187,523$

187,523

Berdasarkan uji signifikansi perbedaan dengan IMB Data Editor versi 21 terdapat hasil t-hitung $=0,111,4 \mathrm{db}=14$ dan $\mathrm{p}$-value $=0.00>0.05$ yang berarti terdapat perbedaan yang signifikan antara pree test dan post test.

\section{Grafik Peningkatan Hasil Pree Test ke Post Test}

Berikut merupakan grafik peningkatan kemampuan antara kelompok yang diberikan perlakuan model servis yang dikembangkan dengan kelompok yang tidak mendapatkan perlakuan. 


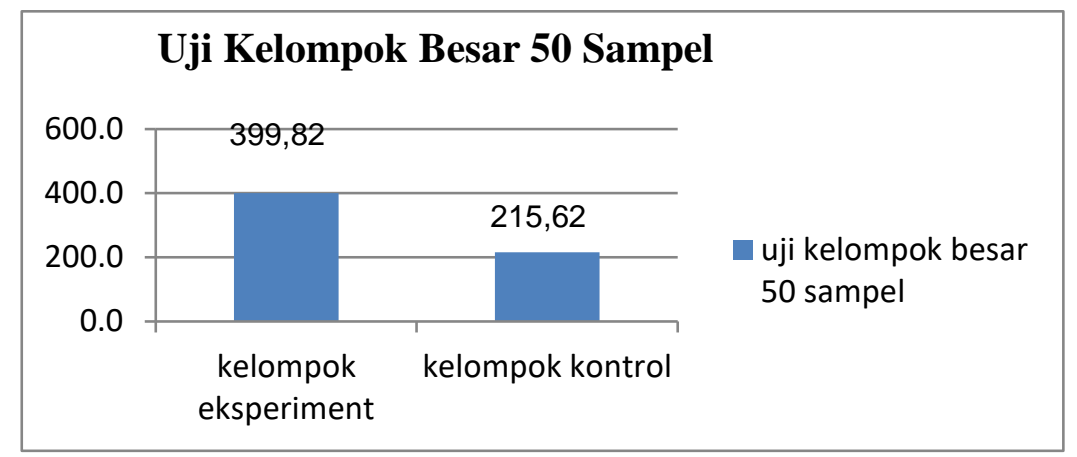

\section{Gambar 2 Grafik Peningkatan Hasil Pree Test ke Post Test}

Berdasarkan grafik di atas, dapat peneliti simpulkan bahwa terdapat perbedaan yang signifikan antara kelompok eksperimen dengan kelompok kontrol dalam peningkatan kemampuan servis sepak takraw pada atlet pemula Kabupaten Sumedang. Faktanya, peningkatan yang dialami oleh kelompok eksperimen terhitung signifikan. Sedangkan kelompok kontrol tidak mengalami peningkatan.

\section{3) Penyempurnaan Produk}

Salah satu contoh penelitian yang dapat dimasukan ke dalam jurnal ini salah satunya adalah penelitian dengan simpulan bahwa produk berupa model latihan penyerangan sepak takraw, setelah diuji dalam uji efektifitas: (1) Model telah terbukti meningkatkan kemampuan penyerangan sepak takraw secara efektif dan efisien pada atlit. (2) Penelitian telah berhasil dilaksanakan dan telah dihasilkan sebuah produk model latihan penyerangan sepak takraw. (3) Dengan model latihan penyerangan sepak takraw yang telah peneliti kembangkan, yang mana subyeknya atlit sepak takraw DKI Jakarta dapat melakukan teknik penyerangan sepak takraw dengan tepat dan benar (Fitrianto, Asmawi, and Lubis 2018). Sejumlah temuan yang di sajikan dalam penelitian ini pada dasarnya dapat dibagi ke dalam tiga jenis keterkaitan dengan penelitian yang sedang peneliti lakukan ini, yaitu (1) penelitian yang memiliki korelasi pengembangan dan pembuatan alat bantu, (2) penelitian yang memiliki korelasi terkait variasi latihan pada sebuah 
teknik dasar cabang olahraga, dan (3) penelitian pengembangan tentang cabang olahraga sepak takraw.

Dan yang terakhir terkait penelitian dengan judul The Influence Of Exercise Method And Reactions Time ToSkills Sprint 100 Meters, yang mengkaji tentang proses latihan yang diperlukan dalam kompetensi pelari 100 Meter. James Tangkudung telah menyimpulkan pada jawaban hipotesis pertamanya, bahwa “Thus, the group's 100 meter sprint skill taught with interval training methods is higher than in the group given continuous training methods. "(Henjilito, Asmawi, and Tangkudung 2018). Dengan demikian, hasil esimpulan dari penelitian tersebut, metode latihan yang seharusnya digunakan adalah metode latihan interval, tentu pada pelaksanaannya tidak jauh menggunakan pengulanganpengulangan lari. Kesamaannya dengan penelitian yang sedang diteliti ini tentang pengulangan-pengulangan gerakan yang dilakukan dalam servis sepak takraw yang juga melalui jadwal yang sama dengan interval training method. Model latihan servis sepak takraw untuk pemula yang dikembangkan dan dibuat oleh peneliti merupakan produk yang bertujuan untuk membantu pelatih, dosen dan guru dalam melatih kemampuan servis sepak takraw, dan sebagai referensi model latihan. Model latihan servis sepak takraw untuk pemula ini dibuat berdasarkan tingkat kebutuhan dalam aktvitas latihan.

\section{PEMBAHASAN}

Di bawah merupakan penjelaskan model latihan servis sudut sepak takraw.

\section{Model latihan servis dengan media pengantar bola dan rod}

Nama

Tujuan

Sarana dan prasarana

Pelaksanaan
: Servis tipuan (trick)

: Memahami dan mampu melakukan Servis tipuan (trick) melalui latihan dengan media pengantar bola (mesin DBH).

: Media pengantar bola, lapangan sepak takraw, Bola sepak takraw, dan net. 
Media pengantar bola berada (mesin DBH) di lapangan yang disimpan diantara lingkaran tekong dan apit, tidak menggunakan bentangan tali rod.

\section{a. Model latihan 1 a.}

1. Media pengantar bola dihidupkan sehingga bola sudah berada di tiang penyangga.

2. Tekong siap dilingkaran servis:

3. Pandangan ke bola yang berada di tiang penyangga;

4. Putarkan kaki ayun kesamping depan dengan tungkai sedikit diluruskan;

5. Kenakan kaki ayun (bebas menggunakan bagian kaki) kepada bola yang berada di tiang penyangga (poin c dapat diulang-ulang untuk melatih bagian kaki yang digunakan untuk menendang bola servis);

6. Pada saat kaki ayun menyentuh bola, pergelangan kaki dikencangkan;

7. Jatuhkan kaki ayun kedepan;

8. Posisi akhir badan menghadap ke net;

9. Bola hasil sepakan melintas di atas net dan jatuh didaerah lapangan lawan;

\section{b. Model latihan 1 b.}

1. Media pengantar bola dihidupkan sehingga bola dapat dijatuhkan dari atas pengantar bola.

2. Tekong siap dilingkaran servis:

3. Pandangan kebola yang jatuh dari atas penyangga bola;

4. Putarkan kaki ayun kesamping depan dengan tungkai sedikit diluruskan;

5. Kenakan kaki ayun (bebas menggunakan bagian kaki) kepada bola yang yang jatuh dari atas pengantar bola (poin c dapat diulang-ulang untuk melatih bagian kaki dan ketepatan perkenaan kaki ayun dengan bola untuk menendang bola servis);

6. Pada saat kaki ayun menyentuh bola, pergelangan kaki dikencangkan;

7. Jatuhkan kaki ayun kedepan; 
8. Posisi akhir badan menghadap ke net;

9. Bola hasil sepakan melintas diatas net dan jatuh didaerah lapangan lawan;

Keterangan : Latihan ini dapat dilakukan dengan menggunakan kaki dominan maupun tidak dominan dan dilakukan secara berulang-ulang/Drills.

\section{Model latihan berpasangan}

Nama

Tujuan

Sarana dan prasarana
: $\quad$ sepak mula tipuan (trick)

: Memahami dan mampu melakukan sepak mula tipuan (trick) melalui latihan secara berpasangan.

: Lapangan sepak takraw, Bola sepak takraw dan net.

Pelaksanaan

\section{a. Model latihan 2 a.}

Dibantu oleh teman yang berdiri disamping depan sambil memegang bola setinggi perut dengan telapak tangan disamping kanan bola (jika tekong dengan kaki ayunnya kaki kanan), lengan yang memegang bola diluruskan. Kaki tumpu berada didepan dengan sedikit ditekuk, sedangkan kaki ayun berada menyilang dibelakang kaki tumpu. Tangan (kiri) disimpan didepan badan, tangan kanan direntangkan untuk menjaga kesetimbangan. Urutan gerakan sebagai berikut.

1. Pandangan kebola yang dipegang teman

2. Putarkan kaki ayun kesamping depan dengan tungkai sedikit di tekuk

3. Kenakan kaki ayun kepada bola yang dipegang oleh teman

4. Jatuhkan kaki ayun kedepan sehingga sejajar dengan kaki tumpu

5. Posisi akhir badan menghadap ke net

\section{b. Model latihan 2 b.}

1. berdiri berhadap-hadapan dengan jarak 1,5 $\mathrm{m}$.

2. kedua sampel (atlet) berperan :
a. sebagai tekong,
b. sebagai apit 
3. tekong bersiap di tempat :

a. kaki tumpu berada didepan kaki ayun $(50 \mathrm{~cm})$

b. posisi tangan diangkat sedikit lebih tinggi diatas rata-rata dada

c. ayunkan kaki ayun ke atas (arah datang bola)

4. lakukan ayunan hingga perkenaan kaki ayun dengan bola terjadi dengan menggunakan ujung kaki. Pada saat akan menyentuh bola,

5. lenturkan pergelangan kaki dan sepak bola dengan tenaga yang dihasilkan oleh tekukan pergelangan kaki tersebut

6. arahkan bola kearah cones yang telah ditetapkan sebelumnya.

7. Biarkan kaki ayun meneruskan gerakannya dan kembali mendarat sebagai gerak lanjutan (followtrough)

8. Posisi cones :

a. Cones 1 berjarak satu meter (1m) di samping belakang kanan lingkaran lawan.

b. Cones 2 berjarak satu meter $(1 \mathrm{~m})$ di samping belakang kiri lingkaran lawan.

c. Cones 3 berjarak $50 \mathrm{~cm}$ di depan sedikit serong kekiri dari lingkaran lawan.

d. Cones 4 berjarak satu meter $(1 \mathrm{~m})$ di depan sedikit serong kekanan dari lingkaran lawan.

10. lakukan 6x tembakan, kemudian saling berganti peran antara A Tekong dan B Apit.

Keterangan : Latihan ini dapat dilakukan dengan menggunakan kaki dominan maupun tidak dominan dengan melibatkan teknik servis dan secara berulangulang/Drills

\section{Model latihan tekong beregu}

Nama

Tujuan

Sarana dan prasarana
: sepak mula tipuan (trick)

: Memahami dan mampu melakukan sepak mula tipuan (trick) melalui latihan secara beregu.

Lapangan sepak takraw, Bola sepak takraw dan net. 
Pelaksanaan :

a. Model latihan 3 a.

1) berdiri saling berhadapan.

2) ketiga sampel (atlet) berperan sebagai :
a. tekong
b. lawan
c. apit

3) tekong bersiap untuk melakukan service :

a. kaki tumpu berada didepan kaki ayun,

b. posisi tangan diangkat lebih tinggi diatas rata-rata dada,

c. ayunkan kaki ayun keatas (arah bola)

4) saat apit melambungkan bola, sepak bola dengan kaki ayun

5) perubahan kaki tumpu menjadi sedikit diangkat (jinjit), dan badan condong kearah depan

6) sepak bola dengan menggunakan ujung kaki (wilayah jemari).

7) Biarkan kaki ayun meneruskan gerakannya dan kembali mendarat sebagai gerak lanjutan (followtrough)

8) arahkan bola kearah cones yang telah di tetapkan sebelumnya (jarak antar cones $50 \mathrm{~cm}$ ) dan berada di lapangan lawan atau setidaknya bola mendekati cones.

9) Setiap tekong diberi kesempatan sebanyak tiga kali.

10) Untuk yang berperan sebagai lawan, berdiri di atas lingkaran lawan, dengan tujuan agar tekong mampu merefleksikan gerakan tipuan secara sadar dan atau tidak sadar hingga terbiasa dengan teknik sepak tipuan tersebut pada pertandingan sesungguhnya. Sebagai lawan, ia juga akan terbiasa memprediksikan kemana bola diarahkan oleh lawan pada pertandingan sesungguhnya.

11).Target sasaran tembakan adalah cones, lakukan secara bergantian dan gulirkan ketiga posisi hingga semua sampel (atlet) melakukan. 


\section{b. Model latihan 3 b.}

Dibantu oleh seorang apit yang bertugas membantu melambungkan bola, dan satu orang berdiri di lingkaran servis lapangan lawan. Tekong berada di lingkaran servis dengan kaki tumpu sedikit ditekuk dan berada di dalam lingkaran servis, sedangkan kaki ayun disilangkan kebelakang kaki tumpu. Tangan kiri digunakan untuk meminta arah bola yang dilempar oleh teman, tangan kanan direntangkan secukupnya disamping badan untuk menjaga kesetimbangan tubuh, pandangan ke arah datangnya bola yang dilempar oleh teman. Rangkaian gerakan sebagai berikut.

1. Tangan kiri meminta arah datangnya bola

2. Lambungkan bola yang dipegang oleh teman sesuai permintaan tekong

3. Putarkan kaki ayun ke samping depan untuk menyepak bola yang dilambungkan oleh teman

4. Ketika menyepak bola, melakukan gerakan tipuan dengan cara tekong diberi kebebasan untuk

a. menggunakan bagian kaki yang digunkan untuk menendang bola

b. menentukan arah dan kecepatan laju bola.

5. Jatuhkan kaki ayun kedepan kaki tumpu setelah menyepak bola

6. Pandangan ke arah laju bola

7. Bola hasil sepakan jatuh di lapangan lawan yang sudah berdiri teman untuk menangkap bola kemudian dikembalikan kepada apit.

8. Setiap tekong diberi kesempatan sebanyak lima kali.

9. lakukan secara bergantian dan gulirkan ketiga posisi hingga semua sampel (atlet) melakukan.

Keterangan : Latihan ini dapat dilakukan dengan menggunakan kaki dominan maupun tidak dominan dengan melibatkan teknik servis dan secara berulangulang/Drills.

\section{Model latihan menggunakan cones}

$\begin{array}{ll}\text { Nama } & : \text { Sepak mula tipuan (trick) } \\ \text { Tujuan } & : \text { Memahami dan mampu melakukan mula }\end{array}$


tipuan (trick) melalui latihan menggunakan sasaran cones

Sarana dan prasarana : Lapangan sepak takraw, Bola sepak takraw, net, dan cones.

pelaksanaan :

\section{a. Model latihan 4 a.}

1. tekong berdiri diatas lingkaran service dengan posisi kedua kaki dibuka selebar bahu.

a. kaki tumpu berada di dalam lingkaran,

b. kaki ayun berada di luar lingkaran.

2. sampel (atlet) berbaris di belakang apit.

3. tekong mengangkat tangannya tanda meminta arah diberikan bola.

4. saat apit melambungkan bola, tekong mengayunkan kaki ayun,

a. pergelangan kaki dilenturkan,

b. tekong bebas menggunakan perkenaan kaki dan bola untuk menyepak (mengarahkan bola) kearah sasaran (cones) yang dituju.

5. arahkan bola ke arah cones (target) yg telah ditetapkan secara acak.

6. Arahkan sesuai dengan keinginan tekong dengan

7. target (posisi cones) :

a. cones (1) $1 \mathrm{~m}$ samping kanan depan lingkaran lawan,

b. cones (2) $1 \mathrm{~m}$ samping kiri depan lingkaran lawan,

c. cones (3) 1,5 m samping kanan belakang lingkaran lawan,

d. cones (4) 1,5 m samping kiri belakang lingkaran lawan,

8. Lakukan sepakan 3x berturut-turut serta arahkan pada sasaran (cones) secara acak.

\section{b. Model latihan 4 b.}

Dibantu oleh seorang teman sebagai apit yang bertugas membantu melambungkan bola sebanyak empat (4) kali. Tekong berada di lingkaran servis dengan kaki tumpu sedikit ditekuk dan berada di dalam lingkaran servis, sedangkan kaki ayun disilangkan kebelakang kaki tumpu. Tangan kiri digunakan 
untuk meminta arah bola yang dilempar oleh teman, tangan kanan direntangkan secukupnya disamping badan untuk menjaga kesetimbangan tubuh, pandangan ke arah datangnya bola yang dilempar oleh teman. Rangkaian gerakan sebagai berikut.

1. Tangan kiri meminta arah datangnya bola;

2. Lambungkan bola yang dipegang oleh apit sesuai permintaan tekong;

3. Ketika menyepak bola, melakukan gerakan tipuan dengan cara tekong diberi kebebasan untuk;

a. menggunakan bagian kaki yang digunkan untuk menendang bola;

b. menentukan kecepatan laju bola.

4. Jatuhkan kaki ayun kedepan kaki tumpu setelah menyepak bola;

5. Pandangan ke arah laju bola;

6. Tekong melakukan sepakan empat (4) kali berturut-turut dengan urutan:

a. Sepakan pertama (1) ke cones nomor empat (4)

b. Sepakan kedua (2) ke cones nomor dua (2)

c. Sepakan ketiga (3) ke cones nomor tiga (3)

d. Sepakan keempat (4) ke cones nomor satu (1)

7. Bola hasil sepakan melambung ke atas net dan jatuh di lapangan lawan yang sudah ditandai oleh cones.

a. cones (1) $1 \mathrm{~m}$ samping kanan depan lingkaran lawan,

b. cones (2) $1 \mathrm{~m}$ samping kiri depan lingkaran lawan,

c. cones (3) 1,5 m samping kanan belakang lingkaran lawan,

d. cones (4) 1,5 m samping kiri belakang lingkaran lawan,

Keterangan : Latihan ini dapat dilakukan dengan menggunakan kaki dominan maupun tidak dominan dengan melibatkan teknik servis dan secara berulangulang/Drills.

\section{Model latihan dengan permainan}

Nama

Tujuan
: Sepak mula tipuan (trick)

: Memahami dan mampu melakukan sepak mula tipuan (trick) melalui latihan dalam 
bentuk permainan

Sarana dan prasarana

: Lapangan sepak takraw, Bola sepak takraw, net, dan cones.

Pelaksanaan :

\section{a. Model latihan 5 a}

1. Sampel (atlet) dibagi menjadi beregu dengan jumlah per regu adalah 5 orang.

2. Setiap regu mendaftarkan regunya masing-masing untuk mengikuti turnamen (permainan).

3. Peraturan pelaksanaan :

a. Durasi permainan 15 menit per satu kali pertandingan.

b. Kapten dari masing-masing regu mengundi dengan cara lempar koin, untuk menentukan bola pertama permainan.

c. Bola hanya bisa di pantulkan (dimainkan) dengan teknik sepak mula tipuan (trick) dan teknik sepak cungkil sebagai awal dari penerimaan bola awal.

\section{b. Model latihan 5 b.}

Melakukan game dengan aturan sederhana tiga (3) lawan tiga (3) dengan rangkaian kegiatan sebagai berikut.

1. Kelempok yang memenangkan toss/undian melakukan servis terlebih dahulu, dan dapat melakukan servis secara bergantian (tidak terpaku satu (1) tekong untuk melakukan servis);

2. Setiap tekong melakukan servis bawah sampai mendapatkan angka/point lima (lima), dari angka/point enam (6) sampai 10 menggunakan servis atas. Tekong melakukan servis harus dengan sistematika gerakan servis yang benar;

3. Ketika menyepak bola, melakukan gerakan tipuan dengan cara tekong diberi kebebasan untuk; 
a. menggunakan bagian kaki yang digunkan untuk menendang bola;

b. menentukan arah dan kecepatan laju bola.

4. Bola hasil servis harus melewati net dan jatuh di lapangan lawan;

5. Angka kemenangan tiap set adalah 10, kelompok yang lebih dulu mencapai angka 10 dinyatakan sebagai pemenang;

6. Jika terjadi terjadi angka/point sembilan (9) sama, maka kemenangan dibatasi sampai angka/point 12.

Keterangan : lakukan pertandingan hingga semua regu ikut dalam permainan

\section{Model latihan gerakan fisik}

Nama

Tujuan

Sarana dan prasarana

Pelaksanaan :

\section{a. Model latihan 6 a.}

1. Gerakan yang harus dilakukan adalah :

a. Berjalan jinjit

1). Sampel (atlet berbaris di sisi lapang memanjang),

2). Jinjitkan kedua kaki

3). Mulai berjalan ke ujung lapangan.

b. Berjalan dengan menggunakan telapak kaki bagian belakang

1). Sampel (atlet berbaris di sisi lapang memanjang),

2). Angkat telapak bagian depan

3). Mulai berjalan ke ujung lapangan dengan menggunakan kaki bagian belakang.

4). Lakukan kedua gerakan tersebut berulang-ulang /drill dengan hitungan minimal 2x 4 bolak balik lapangan.

\section{b. Model latihan 6 b.}


Tekong berdiri didekat lingkaran servis dengan posisi badan menghadap lapangan. Satu orang teman berdiri di lingkaran apit untuk membantu melambungkan bola kepada tekong sebanyak dua (2) kali kesempatan. Urutan gerakan sebagai berikut:

1. Tekong berdiri dengan satu kaki tumpu didepan dan kaki ayun dibelakang kaki tumpu;

2. Angkat kaki ayun kesamping kemudian ke depan atas tinggi sambil menekuk lutut berbarengan dengan kaki tumpu sedikit meloncat-loncat;

3. Gerakan ini dilakukan sebanyak $2 \times 8$ hitungan untuk masing masing tungkai;

4. Setelah selesai tekong diberi waktu istirahat aktif selama 30 detik;

5. Setelah istirahat aktif selama 30 detik tekong kembali bersiap untuk melakukan servis;

6. Tangan kiri meminta arah datangnya bola;

7. Kaki tumpu sedikit ditekuk dan berada di dalam lingkaran servis, sedangkan kaki ayun disilangkan kebelakang kaki tumpu;

8. Lambungkan bola yang dipegang oleh apit;

9. Putarkan kaki ayun ke samping atas untuk menyepak bola yang dilambungkan oleh apit;

10. Ketika menyepak bola, melakukan gerakan tipuan dengan cara tekong diberi kebebasan untuk;

a. menggunakan bagian kaki yang digunkan untuk menendang bola;

b. menentukan arah dan kecepatan laju bola.

11. Jatuhkan kaki ayun kedepan setelah menyepak bola;

12. Pandangan ke arah laju bola;

13. Bola hasil sepakan jatuh di lapangan lawan;

14. Kembali ke posisi awal yaitu berdiri di dekat lingkaran servis untuk melakukan kesempatan kedua.

Keterangan : Latihan ini dapat dilakukan dengan menggunakan kaki dominan maupun tidak dominan dengan melibatkan teknik servis bawah dan atas sepak takraw. 
Berdasarkan treatment yang diberikan, baik pada sampel dengan menggunakan alat bantu dan dengan tidak menggunakan alat bantu, enam (6) variasi latihan di atas telah diuji dengan sejumlah subjek pada kelompok kecil dan kelompok besar serta telah di ketahui bahwa terdapat peningkatan yang signifikan terhadap hasil kemampuan servis corner.

\section{KESIMPULAN}

Berdasarkan data yang diperoleh, dari hasil ujicoba lapangan dan pembahasan hasil penelitian dapat disimpulkan bahwa:

1. Model latihan servis tipuan sepak takraw untuk atlet pemula Kabupaten Sumedang dapat dikembangkan serta dilakukan penerapan untuk peningkatan kemampuan servis sepak takraw.

2. Latihan servis tipuan sepak takraw dengan enam variasi untuk atlet pemula Kabupaten Sumedang dapat dikembangkan serta dilakukan penerapan untuk peningkatan kemampuan servis tipuan atlet pemula kabupaten Sumedang.

3. Model latihan servis tipuan sepak takraw untuk atlet pemula yang telah dikembangkan, telah teruji dan memiliki nilai efektif dan layak digunakan dalam latihan servis sepak takraw.

\section{DAFTAR PUSTAKA}

Borg, Walter R., and Meredith D. Gall. 1983. Instructor's Manual for Educational Research: To Accompany Educational Research: An Introduction. Longman.

Emzir, Emzir. 2008. Metodologi Penelitian Pendidikan. Jakarta: Rajawali Press.

Fitrianto, Ari Tri, Moch Asmawi, and Johansyah Lubis. 2018. "MODEL LATIHAN PENYERANGAN SEPAKTAKRAW." Multilateral Jurnal Pendidikan Jasmani Dan Olahraga 17(1).

Henjilito, Raffly, Moch Asmawi, and James Tangkudung. 2018. "THE INFLUENCE OF EXERCISE METHOD AND REACTIONS TIME TO SKILLS SPRINT 100 METERS." 4:15. 
Dadang Budi Hermawan, (2020)

Model Latihan Servis Tipuan (Trick Service) Sepak Takraw Pemula

Putra, Nusa. 2011. "Research and Development Suatu Pengantar." Jakarta: PT. Rajagrafindo Persada.

Setyosari, Punaji. 2013. Metodologi Penelitian Dan Pengembangan. Jakarta: Fajar Interpratama Mandiri. 